\title{
Conservation through utilization: a case study of the Vulnerable Abies guatemalensis in Guatemala
}

\author{
Uffe Strandby Andersen, José Pablo Prado Córdova \\ Ulrik Bräuner Nielsen, Carsten Smith Olsen, Charlotte Nielsen \\ Marten Sørensen and Johannes Kollmann
}

\begin{abstract}
Conservation through utilization is a controversial strategy that deserves more attention from researchers and practitioners. This case study focuses on Abies guatemalensis, a Vulnerable Mesoamerican conifer that is illegally used for timber, shingles, charcoal and Christmas tree production. Conservation of the remnant populations would preserve some unique montane forests, with concomitant benefits for local water supplies and prevention of landslides. As a conservation tool we suggest establishment of additional A. guatemalensis Christmas tree plantations. These could generate income for local farmers and help halt poaching from natural stands. So far, 51 such plantations have been established in Guatemala but practical knowledge of cultivation is limited and production dominated by a few large plantations. Seed for Christmas tree plantations needs to be carefully selected because there are marked differences among populations in germination, seedling height increment and greenery quality. Insect pests such as the balsam twig aphid Mindarus sp. could limit cultivation. A market study showed that c. $23 \%$ of households in the major Guatemalan cities buy A. guatemalensis Christmas trees but currently only $2.3 \%$ of these are plantation-grown. The prices of illegal and certified Christmas trees are, however, converging, making plantation trees more competitive. Because of the market characteristics and the potential for establishment of plantations, we are moderately optimistic that the conservation through utilization strategy may be successful for this species in Guatemala.
\end{abstract}

Keywords Abies guatemalensis, Christmas tree, Guatemala, market analysis, montane conifer forest, poaching, plantation, regeneration.

Uffe Strandby Andersen (Corresponding author), José Pablo Prado Córdova*, Marten Sørensen and Johannes Kollmann Department of Ecology, University of Copenhagen, Rolighedsvej 21, 1958 Frederiksberg C, Denmark. E-mail usa@life.ku.dk

Ulrik Bräuner Nielsen and Carsten Smith Olsen Forest and Landscape, University of Copenhagen, Kongevej 11, 2970 Horsholm, Denmark.

Charlotte Nielsen Department of Ecology, University of Copenhagen, Thorvaldsensvej 40, 1871 Frederiksberg C, Denmark.

*Also at: Faculty of Agronomy, University of San Carlos of Guatemala, Guatemala.

Received 29 March 2007. Revision requested 24 August 2007.

Accepted 12 October 2007.

\section{Introduction}

Cocio-economic research has established that strict con$\checkmark$ servation by suspension of the rights of local communities to use forests is problematic in developing countries that have extensive and highly dispersed forest resources and limited capacities for enforcement of legislation (Oakerson, 1992; Enters \& Anderson, 1999; Steins \& Edwards, 1999; Edmunds \& Wollenberg, 2003). Conservation strategies are needed that work with local communities to ensure they benefit from conservation measures. The concept of conservation through utilization applies this approach (Newton, 2008). The idea is to decentralize conservation and management responsibilities because people are more inclined to protect and manage their natural resources sustainably if they have decision-making powers over the resource, including the secure right to generate a substantial and stable income (Ostrom, 1990, 1999; Oakerson, 1992; Evans, 1993; Homma, 1996; Arnold, 1998; Arnold \& Ruiz Pérez, 1998; Steins \& Edwards, 1999; Colfer \& Wadley, 2001; Scherr et al., 2002; Angelsen \& Wunder, 2003).

Natural forest products in high demand are often replaced by substitutes, cultivates or synthetics as a response to increasing scarcity and rising prices (Homma, 1996). In this way, domestication is a result of intensified extraction from natural stands. However, domestication can also be an instrument to minimize the pressure on natural stands. Domestication, such as production of plantation trees, can drive down prices and thereby reduce the incentive for poachers to extract from wild resources. In general, successful domestication requires a thorough investigation of marketing chains, tenure rights, experience of the relevant local people with management practices, resilience of local management systems, and technical support (Evans, 1993; Homma, 1996; Marshall et al., 2006). Any cultivated product must also suit the consumers' preferences, and domestication will only lead to forest conservation if extra-sectoral factors, such as demand for agricultural land and community-based management regimes, are conducive to forest conservation.

Here we present a case study in which a framework of ecological and socio-economic factors may allow this conservation through utilization approach to succeed: the use of Abies guatemalensis as a Christmas tree. Our study includes investigations of marketing and cultivation. The information presented comes from an ongoing interdisciplinary 
study that includes both biological and socio-economic components.

\section{A. guatemalensis}

A. guatemalensis is an endemic fir from the upper montane forests of Mexico, Guatemala, Honduras and El Salvador, categorized as Vulnerable on the IUCN Red List (IUCN, 2007). For a morphological, taxonomic and ecological review of the species, see Strandby Andersen et al. (2006). In Guatemala A. guatemalensis occurs in a total of $c .26,000$ ha in montane areas at altitudes of 2,200-3,600 m (Fig. 1). Density is usually low and the species is dominant only in about $4 \%$ of the forests in which it occurs; most stands are fragmented and relatively small (c.500 ha). Germination of A. guatemalensis is low. In a nusery experiment we found a mean percentage germination of only $3.8 \%$ for nine populations (Fig. 2), and germination in the wild is even lower (0.8\%; J.P. Prado Córdova, unpubl. data). Near-natural conifer forests in Guatemala are now confined to the most inaccessible locations, especially in the Departments of Totonicapán, San Marcos and Huehuetenango (Strandby Andersen et al., 2006). These upper montane forests support a high species richness; in addition, they secure the supply of drinking water to local communities and serve as protection against landslides (Veblen, 1976; Nelson \& Chomitz, 2004).

\section{Marketing of A. guatemalensis}

\section{Market status}

A. guatemalensis is listed by the $\mathrm{FAO}$ as threatened throughout its entire range and, as it is included in CITES Appendix
1, all national and international trade and usage is banned (FAO, 1986). The forests in which the species occurs have a long history of intensive exploitation for pasture and clearing for agriculture, and A. guatemalensis is used for timber, shingles and for charcoal production. In addition, since 1960, the species has become popular as a Christmas tree (Strandby Andersen et al., 2006). Branches of adults, and also whole young trees, are illegally harvested, seriously threatening the remaining populations. The clandestine nature of this harvest and the practicalities of local control by communities, means that management of the native stands to allow for regrowth is not an option for conservation. Poachers penetrate protected forests and smuggle branches into urban markets where they are sold as bundles or turned into festoons, wreaths, or Christmas trees made by arranging branches on a lath as assembled semi-natural trees (INAB, 1999). Market surveys carried out in 1995 and 1999 estimated the demand for seminatural A. guatemalensis Christmas trees at 120,000 and 30,000, respectively (INAB, 1999; Aguilar, 2003).

\section{The illegal retail business}

Retailers consist of small family businesses located mainly at one central Christmas market in Guatemala City. They buy branches directly from wholesalers' lorries entering markets at night or more often from secondary wholesalers. We interviewed 67 retailers in December 2004 regarding trade conducted in 2003, and asked about quantities of branches purchased, prices and costs related to the production of assembled Christmas trees, festoons and wreaths. The assembled Christmas trees were sold at an average price of USD $14.4 \pm$ SE $0.7(n=67)$; this information corresponds to information gathered from

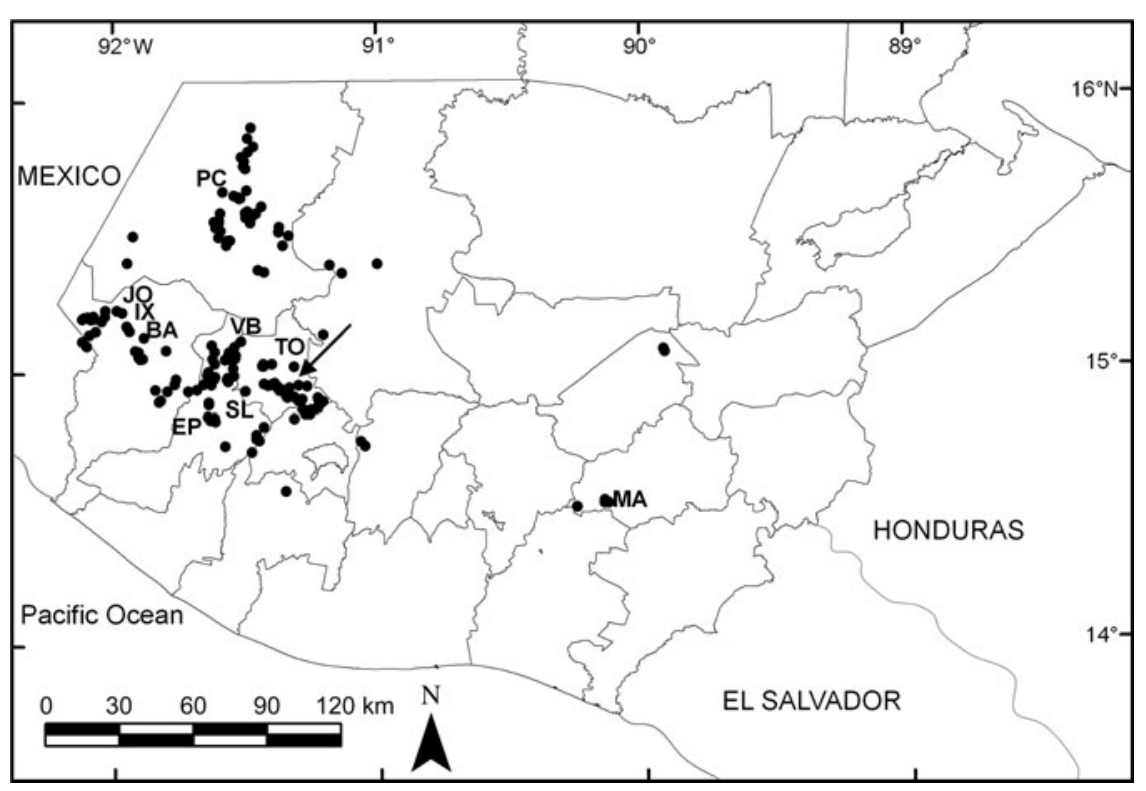

FIG. 1 Distribution map of Abies guatemalensis forests (black dots) in Guatemala, with the location of the two nurseries (black arrow), and the origin of the nine provenances studied (with Department): MA, Mataquescuintla (Jalapa); EP, El Eden Palestina de los Altos (Quetzaltenango); BA, Buenos Aires (San Marcos); TO, Totonicapán (Totonicapán); SL, Sibilia La Laguna (Quetzaltenango); VB, San Vicente Buenabaj (Quetzaltenango); JO, San José Ojetenan (San Marcos); PC, Puerta del Cielo (Huehuetenango); and IX, Ixchiguán (San Marcos). 


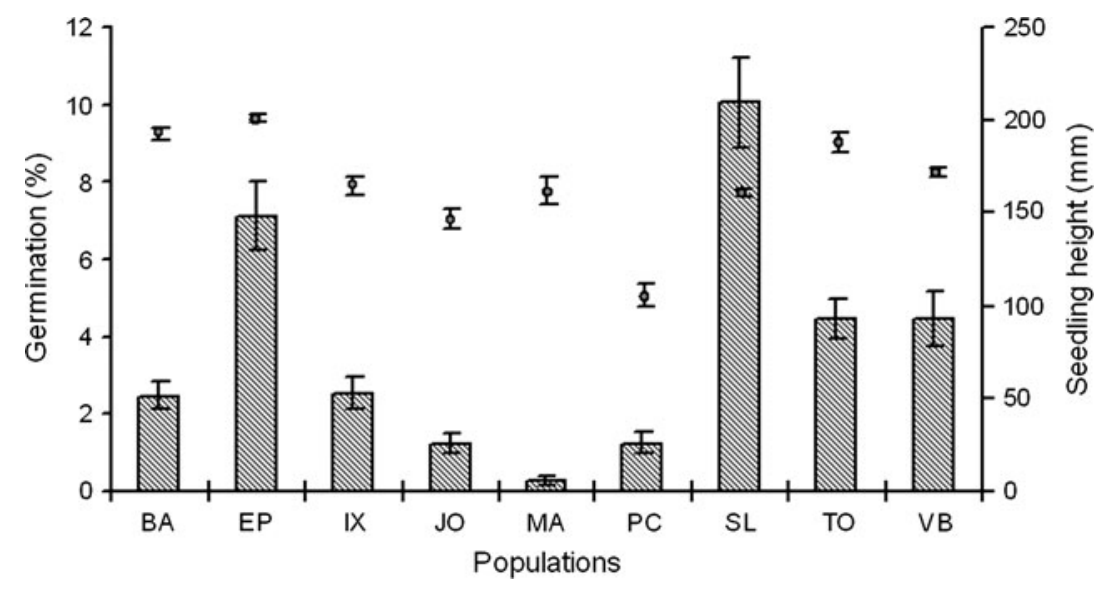

FIg. 2 Percentage germination (columns, $\mathrm{n}=2,000$ seeds per provenance) and mean \pm SE seedling height (solid circles, $\mathrm{n}=50-750$ seedlings) of nine provenances of Abies guatemalensis (Fig. 1) after 14 weeks in two nurseries at 2,300 and 2,900 $\mathrm{m}$. Percentage germination and seedling height for the two nurseries were pooled because there were no significant differences between them. Order of provenances is by increasing altitude $(2,600-$ 3,381 m). Provenance abbreviations as Fig. 1. consumers (USD 16.2; Fig. 3). Branches are sold by the socalled dozen, although this does not necessarily equate to 12. The construction of one assembled 2-m tree requires a mean of $6.2 \pm$ SE $0.3(n=109)$ 'dozens' of branches (one 'dozen' consists of a mean of $10.2 \pm$ SE 3.2 branches, and has a mean weight of $2.1 \pm \mathrm{SE} 0.9 \mathrm{~kg}, \mathrm{n}=109$ ). The variable costs of production are staples and lath (mean USD $1.34 \pm$ SE 0.06 per tree, $\mathrm{n}=67$ ) and branches (mean USD $1.44 \pm$ SE 0.06 per 'dozen', $n=67$ ). Fixed costs per season are transportation to the market place (mean USD $32.3 \pm \mathrm{SE}$ $4.8, \mathrm{n}=67$ ), market fee and material for the stall (mean USD 113.3 \pm SE 16.5, $\mathrm{n}=67$ ) and light (mean USD $17.0 \pm$ SE 3.6, $\mathrm{n}=67$ ). Taking all the costs into consideration, the retailer has a mean total income of USD $938 \pm$ SE 312 $(\mathrm{n}=67)$ for constructing and selling A. guatemalensis Christmas trees during November and December, including a minor income from wreaths and festoons. This is a relatively high income compared to alternative income generating sources such as cultivation of potatoes (USD 206 per month) and remittances from family members working in the USA (USD 42 per month; Ignosh, 2005; Prado Córdova, 2007).

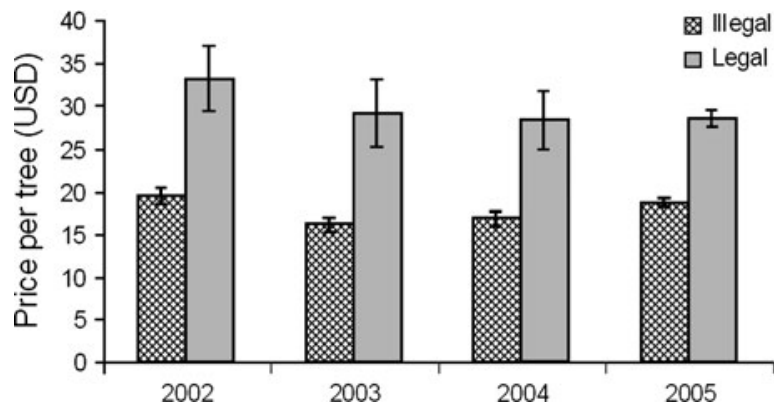

FIG. 3 Mean retail prices \pm SE of illegal and certified Abies guatemalensis (based on 932 interviews in December 2005) for 2002-2005.

\section{Demand for Christmas trees}

A national survey in December 2005 and spring 2006 of 592 customers randomly encountered in various market places in Guatemala City ( $\mathrm{n}=392)$, Quetzaltenango (50), Escuintla (50), Retalhuleu (50) and Mazatenango (50), and 401 consumers encountered in the Roosevelt market (Guatemala City) revealed that trees made of illegally harvested A. guatemalensis branches had a market share of $46 \%$, whereas only $2 \%$ of the consumers purchased certified plantation trees. Plastic trees make up $35 \%$ of purchases, and only $3 \%$ of the consumers chose imported trees from North America. Approximately 50\% of households buy a Christmas tree of some type. Based on available demographic data for five sampled cities (INE, 2002) and average household size (mean $6.08 \pm$ SE 0.1 ) we estimate that c. 111,00o illegal A. guatemalensis Christmas trees were bought in Guatemala in 2005, compared to $c .5,500$ certified trees. The real price paid by consumers for illegally produced A. guatemalensis was stable for 20022005, fluctuating over USD 16.2-19.3 without any clear trend (Fig. 3). On the other hand, the price of certified $A$. guatemalensis trees has declined by $14 \%$ from USD 33.2 in 2002 to USD 28.6 in 2005 . The reason for this reduction is not clear, however. If this trend continues the prices of illegal and certified A. guatemalensis Christmas trees will soon converge.

\section{Consumers' preferences and environmental awareness}

Preferences of consumers were markedly different from their actual choice. Twenty percent of consumers stated certified A. guatemalensis were their most favoured Christmas tree; $20 \%$ prefered assembled semi-natural, and $26 \%$ had no particular preference among the two types. Plastic trees were favoured by $18 \%$, imported Abies trees by $4 \%$, and a group consisting of mainly Pinus and Cupressus 
species constituted $12 \%$ (U. Strandby Andersen, unpubl. data). Consumer awareness of the threatened status of $A$. guatemalensis was high. The species' rarity and protected status was known to $79 \%$ of the informants (U. Strandby Andersen, unpubl. data). This apparent environmental awareness corresponded with the explanations given by consumers of certified Christmas trees. Almost a third of the consumers of certified Christmas trees did not buy illegal trees because they believe it is better for the environment to choose certified trees, and more than half of the consumers of certified Christmas trees did not buy the illegal trees because they were aware that it is forbidden. However, this knowledge did not prevent $46 \%$ of people from buying the illegally produced trees. Certified trees are apparently still too expensive compared to the assembled semi-natural trees, as pointed out by $41 \%$ of the buyers of illegal trees. This consumer statement is supported by our findings related to prices; certified trees were $c .50 \%$ more expensive in 2005 than those produced illegally (Fig. 3). The certified trees were also rejected because of their poor shape $(35 \%)$ or because it was difficult to find market places where they are traded (23\%).

\section{Cultivation of A. guatemalensis}

\section{Plantation management practice}

Christmas trees have become fashionable among the middle class of Guatemala City since the 1950s (Standley \& Steyermark, 1958; INAB, 1999), and the first plantations of A. guatemalensis were established in the early 1970 s in response to increasing demand. About 50 plantations were registered by 2007 , covering an area of c. 125 ha (INAB, 2004). Plantation production requires an official permit and certification by the National Forest Institute. Only 16 plantations covering an area of 20 ha are active (for reasons that are unclear) and produced 3,000-5,000 trees annually during 2002-2005 (M.M. Velásquez, pers. comm.). A. guatemalensis Christmas trees are produced in a simple planting and management system with harvesting after 4-8 years (Plate 1). The traditional cultivation practice involves lateral shearing, as growth of the species is rapid and results in long branches and large distances between whorls.

\section{Insect pests in plantations}

In 1995 an aphid was recorded causing damage in several plantations of A. guatemalensis (C. Escobar \& R. Estrada, pers. comm.) and in 2005 the insect was identified as belonging to the Mindarus abietinus complex (Hemiptera: Aphididae; O. Heie \& S. Harding, pers. comm.), and recent morphological evidence suggests that it is a new subspecies or species of Mindarus (C. Nielsen, unpubl. data). Mindarus spp. are a serious pest of plantations in the USA

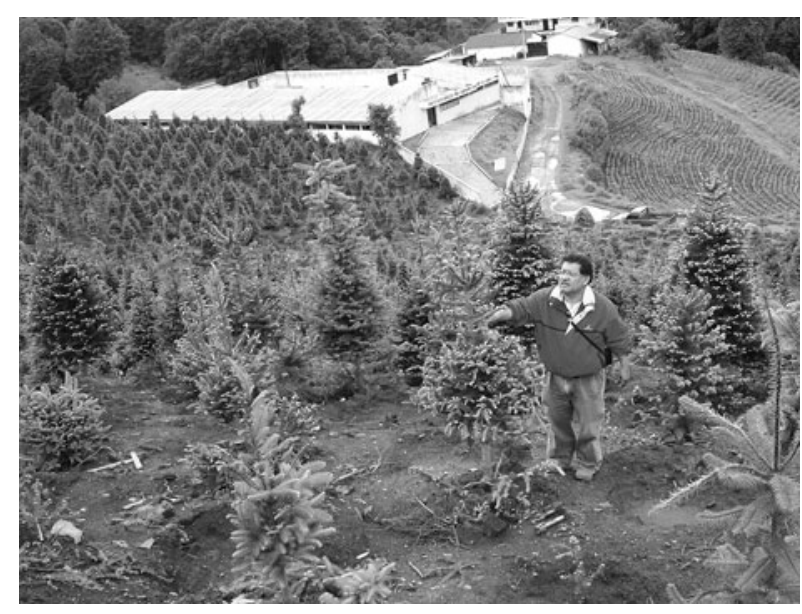

Plate 1 Abies guatemalensis plantation (1.8 ha) in El Eden Palestina de los Altos (at 2,600 m) in the Department of Quetzaltenango (Fig. 1). This plantation produces c. 500 high quality Christmas trees annually, with intensive management.

(Fondren \& McCullough, 2003) and we therefore investigated the extent of the problem in Guatemala. Ten plantation owners were interviewed in 2007 about infestation problems during 2002-2006. Only one respondent claimed that severe problems had been caused by $M$. abietinus, whereas most owners stated that the pest occurs regularly but is of minor importance (U. Strandby Andersen, unpubl. data).

Two nurseries, five plantations and three natural forests were visited in June 2006 in the Departments of Totonicapán, San Marcos, Quetzaltenango and Huehuetenango to assess the abundance of Mindarus sp. and its natural enemies. We found Mindarus sp. at all locations, with individual shoots harbouring densities as high as $>_{100}$ aphids per current year shoot, and with average damaged shoots of up to $87 \%$ in plantations and $62 \%$ in natural stands. Even though A. guatemalensis is capable of outgrowing Mindarus sp. damage by late summer (Nettleton \& Hain, 1982), it seems unlikely that damage of the magnitude observed will be compensated for. We also found natural insect predators of aphids (syrphids, coccinellids, cecidomyiids, anthocorids, cantarids and chrysopids) and parasitoids and entomopathogenic fungi. Plantation owners expressed only minor problems with Mindarus sp. and we found that entomopathogenic fungi and syrphid larvae can play a principal role in suppressing Mindarus sp. on $A$. guatemalensis. However, plantation areas are currently small (1.77 \pm SE 0.32 ha) and any increase in plantation area could involve the risk of pest outbreaks.

\section{Variation among provenances}

Genotype quality of Abies species is important in Christmas tree cultivation because of the short rotation system and high value of the crop. Provenance analysis of Abies spp. 
has shown marked differences in growth, number of saleable trees and economic return (Arnold et al., 1994; Madsen, 1994; Hansen et al., 2004). Hence, identifying good provenances is a successful way to improve product quality and thereby strengthen the demand for plantation trees.

Only limited information is available on genetic variation in quantitative and phenological characteristics of $A$. guatemalensis. We therefore evaluated nine provenances from the highlands of Guatemala in a nursery experiment (Strandby Andersen et al., 2008). Germination rates, germination period, survival rates, height, flushing and the number of secondary branches were examined, and the provenances showed significant differences for all traits. The variation in germination (1-10\%) and seedling height $(10-22 \mathrm{~cm}$ ) after 14 months was substantial (Fig. 2). There were negative correlations of these traits with altitude when the population originating from the lowest location (Mataquesquintla), with a small sample size, was excluded (Pearson Product Moment correlation: germination $r^{2}=$ $0.37, \mathrm{P}=0.11$; height $r^{2}=0.55, \mathrm{P}=0.03$ ). Two provenances from the central part of the distribution area showed superior nursery attributes with highest germination percentages and densest distribution of secondary branches (Sibilia la Laguna) and tallest seedlings (El Eden Palestina de los Altos).

\section{Post-harvest quality}

A highly valued trait of A. guatemalensis is its unique scent, which is prominent from cut branches used in assembled semi-natural trees but also present in natural young trees. In North America, as well as in Europe, good needle retention during display is highly valued by consumers, and has caused a change in choice towards Abies spp. (Nielsen \& Chastagner, 2005). For many species needle loss is strongly related to drying, and therefore influenced by storage time and conditions (Chastagner \& Riley, 2003; Nielsen \& Chastagner, 2005). Climatic data for December in Guatemala City for 1993-2003 show an average temperature of $17.9^{\circ} \mathrm{C}, 198 \mathrm{~h}$ of sunshine and a relative humidity of $64 \%$ (INSIVUMEH, 2007), conditions that are unlikely to favour needle retention and therefore of concern for selection of suitable provenances for future plantations. However, in general, A. guatemalensis has the reputation of being a good needle retaining species.

In August 2006 a post-harvest quality study was carried out by sampling branches from four plantations of $A$. guatemalensis (Prado Córdova, 2007). The different populations showed clear variation in scent during the display time of 21 days. Scent emission in two populations peaked after 10-15 days, one had hardly any scent, and one a strong scent during the first 15 days and a slow decrease until day 21. Drying rates were similar to other Abies spp. (Chastagner \& Riley, 2003; Helligmann \& Brown, 2005;
Nielsen \& Chastagner, 2005). Based on these observations, post-harvest quality is a matter of concern for successful commercialization of the species, and is influenced by factors that include site, time of harvest, provenance, and effect of storage conditions.

\section{Discussion}

A summary of the constraints and opportunities for improved conservation and enhanced livelihood benefits from A. guatemalensis in Guatemala is given in Table 1. The remnant populations of the species are small, scattered and located far from the capital. Protection is cumbersome and faces serious institutional and financial constraints as both resources and skilled staff are limited. Furthermore, direct observations at the markets in December 2004 and 2005, and interviews with key persons revealed a lack of law enforcement and several episodes of bribing. It is tempting to suggest a strengthening and empowering of the authorities in charge of protection but too much focus on confiscating illegally harvested branches would be expensive and could raise prices on the black market and thereby increase the incentive to poach (Fischer, 2004; Courchamp et al., 2006; Damania \& Bulte, 2007). Only a small amount of branches are confiscated by the authorities compared to the estimated number of Christmas trees sold in the illegal markets. Branches equivalent to 544, 402, 269 and 265 assembled semi-natural trees were taken by the police in 2002, 2004, 2005 and 2006, respectively (M.M. Velásquez, pers. comm.). Thus, a conventional protectionist approach to conservation does not seem to be working.

Populations of A. guatemalensis continue to be threatened by foliage poachers, timber and firewood extraction, grazing and conversion to arable land (Cabrera Gaillard, 1996). However, pressure from agriculture will probably lessen in the future because the role of commercial agriculture in Guatemala is declining (Vakis, 2003; Dardón, 2004). However, A. guatemalensis is still the preferred Christmas tree and demand will probably grow because of increasing urbanization (3.7\% annual rate, 2000-2005), wealth (annual increase 3\% GNP per capita, 1998-2004), and human population (2.6\% growth, 1980-1998; expected 2.1-2.3\% until 2015; World Bank, 2005; UNHABITAT, 2006). Therefore, alternative policies to traditional conservation strategies need to be considered.

Conservation through domestication seems a feasible strategy in the case of A. guatemalensis. Establishment of additional plantations to meet increasing demand, combined with enforcement of existing legislation to prevent trade in branches, could make foliage poaching unprofitable in the long-term. There are a number of indicators that seem to support this development, although some caveats need to be considered. For example, it is essential to understand the impacts of increased domestication on 
TABLE 1 Summary of the ecological and socio-economic constraints and opportunities for Christmas tree production and marketing in Guatemala.

\begin{tabular}{|c|c|}
\hline Constraints & Opportunities \\
\hline $\begin{array}{l}\text { Forest grazing, firewood consumption \& poaching of branches } \\
\text { for Christmas trees }\end{array}$ & $\begin{array}{l}\text { Willingness to protect forests because of cultural values, supply } \\
\text { of drinking water \& prevention of landslides }\end{array}$ \\
\hline Low natural regeneration & $\begin{array}{l}\text { Regeneration benefits from canopy openings \& litter removal; } \\
\text { abundant seed production }\end{array}$ \\
\hline Low germination \& short seed viability & $\begin{array}{l}\text { Increase germination by using specific genotypes \& improving } \\
\text { seed technology }\end{array}$ \\
\hline Insect pests in monoculture plantations \& natural stands & Biological control \& intercropping; chemicals \\
\hline Low plantation production & $\begin{array}{l}\text { Increased involvement of communities in Christmas tree } \\
\text { plantation management by improved technical } \\
\text { assistance \& financial support; provenance selection }\end{array}$ \\
\hline Irregular shape of plantation trees & Selecting suitable genotypes \& professional shearing \\
\hline $\begin{array}{l}\text { Limited involvement of local communities in plantation } \\
\text { management }\end{array}$ & $\begin{array}{l}\text { Communities possess experience with nursery } \\
\text { management \& forest protection; plantations on } \\
\text { communal land; legal \& technical support }\end{array}$ \\
\hline Market dominated by illegally produced trees & Consumers are interested in certified trees \\
\hline Decreasing supply from natural forests & $\begin{array}{l}\text { Rising demand \& prices as Christmas trees are a luxury good, } \\
\text { making plantation establishment financially more attractive }\end{array}$ \\
\hline Costs of plantation tree production unknown & $\begin{array}{l}\text { Reduce costs through research, e.g. as above on increased } \\
\text { production, knowledge of pests }\end{array}$ \\
\hline Higher prices of certified compared to illegal trees & Prices are converging \\
\hline
\end{tabular}

transaction costs and consumer preferences (Fischer, 2004; Damania \& Bulte, 2007). It is unlikely that transaction costs in the illegal trade will be changed by the production of a higher number of certified trees because the two production-to-consumption systems are different. The illegal trade relies on transportation of branches harvested in natural forests only, whereas the legal trade operates with harvest and transport of whole trees. Therefore, it is unlikely that smuggling will become easier and that illicit materials can be sold under the cover of legal supplies provided that the harvest of branches from plantations is not allowed. Consumer preferences could be altered by an increase in certified supplies making illegally produced 'authentic' Christmas trees more desirable (Courchamp et al., 2006). However, our study shows an equal preference for certified Christmas trees and assembled semi-natural trees $(20 \%)$, and $26 \%$ of the consumers were indifferent with respect to the two types. Furthermore, considering the awareness of many consumers of the protected status of the species, a decrease in the price of certified trees would reduce the likelihood that consumers prefer illegal trees if certified trees became more readily available. Thus, it is unlikely that transaction costs and consumer preferences will be changed by the production of more certified trees. However, there is a risk that the additional supply of certified trees will displace the demand on plastic trees or create a new demand from consumers who avoided buying Christmas trees at all because of the illicit nature of the market; i.e. the demand on illegal trees will remain unchanged. Nevertheless, our data suggest that consumers buying illegal trees do so because of prices (41\%), lack of supply (23\%) or bad tree shape (35\%). The inferior qualities of the certified trees compared to the illegal assembled semi-natural trees is a matter that can be tackled with improved plantation management, including appropriate provenance selection and systematic shearing.

Side shaping or shearing methods are extensively developed for true firs Abies spp., Douglas fir Pseudotsuga spp. and pines Pinus spp., and they are an integrated part of Christmas tree production, especially in North America (Landgren et al., 2003; Hinesley \& Derby, 2004). Based on the vigorous growth, good branching and re-sprouting of A. guatemalensis (U. Bräuner Nielsen, pers. observ.), systematic shearing techniques can be developed and implemented for the production of A. guatemalensis Christmas trees. The efficiency of these techniques probably means that a variety of seed sources can be used, which would support usage and conservation of several local seed sources. However, choice of superior provenances would be a valuable tool for optimizing production.

Involvement of local communities in cultivation by commercialization is regarded as essential for improving rural livelihoods (Evans, 1993; Arnold \& Ruiz Pérez, 1996, 1998; Neumann \& Hirsch, 2000; Marshall et al., 2006). A comparison of traditional Christmas tree management with an agroforestry system including A. guatemalensis, a reforestation programme, and cultivation of potatoes suggested that Christmas tree cultivation (both with and without reforestation subsidies) returned an annual profit larger than the three alternatives and thereby constitutes an attractive income source for local communities (Ignosh, 2005). 
Despite the fact that only $10 \%$ of the registered plantations are owned and managed by local communities, several communities have expressed interest in establishing plantations and have gained experience with both seed collection and nursery establishment. Local communities could on one hand benefit from legal production of a valuable new crop and on the other hand the effort would protect the remnant forests of A. guatemalensis to secure seed supply, maintain water resources and prevent natural hazards. Hence, provided that more plantations are established, local communities are involved, plantation management techniques are improved and knowledge disseminated, and actions taken to minimize the illicit market, we are moderately optimistic that the conservation through utilization strategy may be successful for this species in Guatemala. To facilitate the establishment of additional plantations and to improve plantation management, we have contributed, with Danish Christmas tree experts, to courses in Christmas tree production in Guatemala, supported publications on processing and storage of A. guatemalensis seeds and plantation management guidelines, established three provenance experiments to test long-term performance, and are now organizing a visit for the A. guatemalensis national coordinator to Denmark for an examination of Danish Christmas tree production and marketing.

\section{Acknowledgements}

We are grateful to a large number of Guatemalan students, colleagues, administrators, plantation owners and people from local Maya communities for supporting our investigations. The project would not have been possible without the generous support provided by Juan José Castillo Mont. Our research was funded by a $\mathrm{PhD}$ grant to USA from the University of Copenhagen, by the Danish Research Council for Development Research (No. 91160), WWF and the Danish ReNED organization.

\section{References}

A guilar, F. (2003) Comercio Ilegal. Primer Taller Nacional del Pinabete. INAB, Guatemala City, Guatemala.

Angelsen, A. \& Wunder, S. (2003) Exploring the Forest - Poverty Link: Key Concepts, Issues and Research Implications. Occasional Paper 40. CIFOR, Bogor, Indonesia.

A rnold, J.E.M. (1998) Managing Forests as Common Property. FAO Forestry Paper 136. Food and Agriculture Organization, Rome, Italy.

Arnold, J.E.M. \& Ruiz Pérez, M. (1996) Framing the issues relating to non-timber forest products research. In Current Issues in Non-timber Forest Products Research (eds M. Ruiz Pérez \& A. Ingles), pp. 1-18. CIFOR/ODA, Bogor, Indonesia.

Arnold, J.E.M. \& Ruiz Pérez, M. (1998) Role of NTFPs in conservation and development. In Incomes from the Forest. Methods for the Development and Conservation of Forest Products for Local Communities (eds E. Wollenberg \& A. Ingles), pp. 11-41. CIFOR, Bogor, Indonesia.
Arnold, R.J., Jett, J.B. \& McKeand, S.E. (1994) Natural variation and genetic parameters in fraser fir for growth and Christmas tree traits. Canadian Journal of Forest Research, 24, 1480-1486.

Cabrera Gaillard, C. (1996) Síntesis histórica de la deforestación en Guatemala. Facultad Latinoamericana de Ciencias Sociales, Universidad de San Carlos de Guatemala, Guatemala City, Guatemala.

Chastagner, G.A. \& Riley, K.L. (2003) Postharvest quality of noble and Nordmann fir Christmas trees. Hortscience, 38, 419-421.

Colfer, C.J.P. \& Wadley, R.L. (2001) From 'participation' to 'rights' and responsibilities in forest management. In People Managing Forests - The Links Between Human Well-Being and Sustainability (eds C.J.P. Colfer \& Y. Byron), pp. 278-299. Resources for the Future, Washington, DC, USA.

Courchamp, F., Angulo, E., Rivalan, P., Hall, R.J., Signoret, L., BulL, L. et al. (2006) Rarity values and species extinction: the anthropogenic Allee effect. PLoS Biology, 4, 415.

Damania, R. \& Bulte, E.H. (2007) The economics of wildlife farming and endangered species conservation. Ecological Economics, 62, 461-472.

Dardón, J. (2004) Migración internacional, espiral perversa de crecimiento con nuevas pobrezas. FLACSO, Encuentro Internacional sobre Pobreza, 16-20 agosto 2004, Antigua, Guatemala.

Edmunds, D. \& WollenberG, E. (2003) Local Forest Management - The Impacts of Devolution Policies. Earthscan Publications, London, UK.

Enters, T. \& Anderson, J. (1999) Rethinking the decentralisation and devolution of biodiversity conservation. Unasylva, 50, 6-11.

Evans, M.I. (1993) Conservation by commercialization. In Tropical Forests, People and Food - Biocultural Interactions and Applications to Development (eds C.M. Hladik, A. Hladik, O.F. Linares, H. Pagezy, A. Semple \& M. Hadley), pp. 815-822. Parthenon Publishing, Carnforth, UK.

FAO (1986) Databook on Endangered Tree and Shrub Species and Provenances. FAO Forestry Paper 77. Food and Agriculture Organization, Rome, Italy.

Fischer, C. (2004) The complex interactions of markets for endangered species products. Journal of Environmental Economics and Management, 48, 926-953.

Fondren, K.M. \& MCCullough, D.G. (2003) Phenology and density of balsam twig aphid, Mindarus abietinus Koch (Homoptera: Aphididae) in relation to bud break, shoot damage, and value of fir Christmas trees. Journal of Economic Entomology, 96, $1760-1769$.

Hansen, O.K., Bräuner Nielsen, U., Edvardsen, Ø.M., Brynjar SkÚlason, B. \& SKA GE, J.O. (2004) Nordic provenance trials with Abies lasiocarpa and Abies lasiocarpa var. arizonica: three-year results. Scandinavian Journal of Forest Research, 19, 112-126.

Helligmann, R.B. \& Brown, J.H. (2005) Postharvest needle retention and moisture characteristics of Cannan fir compared with four other Christmas tree species. Northern Journal of Applied Forestry, 22, 268-274.

HinesLey, L.E. \& DeRB Y, S.A. (2004) Growth of fraser fir Christmas trees in response to annual shearing. Hortscience, 39, 1644-1646.

Номм А, A.K.O. (1996) Modernisation and technological dualism in the extractive economy in Amazonia. In Current Issues in NonTimber Forest Products Research (eds M. Ruiz Pérez \& J.E.M. Arnold), pp. 59-81. CIFOR, Bogor, Indonesia.

Ignosh, J.P. (2005) Pinabete - one opportunity towards the sustainable development of the Guatemalan highlands. MSc thesis, University of Minnesota, Twin Cities, USA.

INAB (Instituto Nacional de Bosques) (1999) Estudio de mercado Arbol navideño de Pinabete (Abies guatemalensis). INAB, Guatemala City, Guatemala. 
INAB (Instituto Nacional De Bosques) (2004) Diagnóstico de las plantaciones de Pinabete (Abies guatemalensis Rehder) en Guatemala. INAB, Guatemala City, Guatemala.

INE (2002) Instituto Nacional de Estadística de Guatemala. Guatemala City, Guatemala. Http://www.ine.gob.gt/censosA.html [accessed 8 March 2007].

INSIVUMEH (2007) Instituto Nacional de Sismología, Vulcanología, Meteorología e Hidrología. Http://www.insivumeh.gob.gt/meteorologia/ESTACIONES/GUATEMALA/ [accessed 14 March 2007].

IUCN (2007) 2007 IUCN Red List of Threatened Species. IUCN, Gland, Switzerland. Http://www.redlist.org [accessed 16 January 2008].

Landgren, C., Fletcher, R., Bondi, M., Barney, D. \& Mahoney, R. (2003) Growing Christmas trees in the Pacific Northwest. PNW 6. Oregon State University, Corvallis, University of Idaho, Moscow, and Washington State University, Pullman, USA.

Madsen, S.F. (1994) Provenance trial of Abies nordmanniana and Abies bornmülleriana for Christmas tree production in North Sealand. Forest and Landscape Research, 1, 143-166.

Marshall, E., Schreckenberg, K. \& Newton, A.C. (2006) Commercialization of Non-timber Forest Products: Factors Influencing Success. Lessons Learned from Mexico and Bolivia and Policy Implications for Decision-makers. UNEP World Conservation Monitoring Centre, Cambridge, UK.

Nelson, A. \& Chomitz, K.M. (2004) The forest-hydrology-poverty nexus in Central America: an heuristic analysis. World Bank Policy Research Working Paper, 3430, 1-39.

Nettleton, W.A. \& Hain, F.P. (1982) The life history, foliage damage, and control of the balsam twig aphid, Mindarus abietinius (Homoptera: Aphididae), in fraser fir Christmas tree plantations of western North Carolina. The Canadian Entomologist, 114, 155-165.

Neumann, R.P. \& Hirsch, E. (2000) Commercialization of Nontimber Forest Products: Review and Analysis of Research. CIFOR, Bogor, Indonesia.

Newton, A.C. (2008) Conservation of tree species through sustainable use: how can it be achieved in practice? Oryx, 42, 195-205.

Nielsen, U.B. \& Chast agner, G.A. (2005) Genetic variation in postharvest needle retention among Nordmann fir families and grafted clones. Scandinavian Journal of Forest Research, 20, 304-312.

OAKerson, R.J. (1992) Analysing the commons: a framework. In Making the Commons Work: Theory, Practice, and Policy (ed. D.W. Bromley), pp. 41-59. Institute for Contemporary Studies Press, San Francisco, USA.

Ostrom, E. (1990) Governing the Commons: The Evolution of Institutions for Collective Action. Cambridge University Press, Cambridge, UK.
Ostrom, E. (1999) Self-Governance and Forest Resources. Occasional Paper 20. CIFOR, Bogor, Indonesia.

Prado Córdova, J.P. (2007) Conservation by cultivation: linkages between an endangered endemic fir (Abies guatemalensis Rehder) and peasant economies in the western highlands of Guatemala. $\mathrm{PhD}$ thesis, University of Copenhagen, Copenhagen, Denmark.

Scherr, S.J., White, A. \& Kaimowitz, D. (2002) Making Markets Work for Forest Communities. Policy Brief. CIFOR, Bogor, Indonesia.

Standley, P.C. \& Steyermark, J.A. (1958) Abies guatemalensis in flora of Guatemala. Fieldiana: Botany, 24, 37-40.

Steins, N.A. \& Edwards, V.M. (1999) Platforms for collective action in multiple-use common pool resources. Agriculture and Human Values, 16, 241-255.

Strandby Andersen, U., Prado Córdova, J.P., Sørensen, M. \& Kollmann, J. (2006) Conservation and utilisation of Abies guatemalensis Rehder (Pinaceae) - an endangered endemic conifer in Central America. Biodiversity and Conservation, 15, 3131-3151.

Strandby Andersen, U., Prado Córdova, J.P., Bräuner Nielsen, U. \& Kollmann, J. (2008) Provenance variation in germination and seedling growth of Abies guatemalensis Rehder. Forest Ecology and Management, 255, 1831-1840.

UNHABITAT (2006) United Nations Human Settlements Programme. Http://www.unhabitat.org/habrdd/conditions/ centamerica/guatemala.htm [accessed 28 June 2006].

VAKIs, R. (2003) Guatemala: Livelihoods, Labor Markets, and Rural Poverty. Guatemala Poverty Assessment (GUAPA) Program, Technical Paper No. 1. World Bank, Washington, DC, USA.

Veblen, T.T. (1976) The urgent need for forest conservation in highland Guatemala. Biological Conservation, 9, 141-154.

WORLD BANK (2005) World Development Indicators. World Bank, Washington, DC, USA.

\section{Biographical sketches}

Uffe Strandby Andersen and José Pablo Prado Córdova are working on an interdisciplinary project on the conservation and utilization of Abies guatemalensis. ULRIK BRÄUNER NIELSEN is interested in forest genetics, with a focus on Christmas tree provenances. Carsten SMith Olsen is a socio-economic researcher focusing on commercial medicinal plants and local forest management. Charlotte Nielsen specializes in forest insect pests and biological control. MARTEN SøRENSEN carries out research on the systematic botany of tropical and subtropical crops. JOHANNES KOLlmann is a plant ecologist working on plant dispersal and regeneration. 